\title{
Developing Critical Thinking Skills through School Teacher Training 'Training and Development Personnel' Model and Their Determinants of Success
}

\author{
Slameto
}

\begin{abstract}
Critical thinking skills are essential skills for life, work, and function effectively in all other aspects of life. The role of teachers is now more complex than ever; $A$ teacher is an agent of change; Associated with the development of critical thinking, the practice of teaching and learning by teachers in primary schools encourage the achievement of the necessary critical thinking skills. One factor is the lack of understanding of the teachers' teaching methods that can improve critical thinking skills. Therefore need to empower teachers. One model is 'Training and Development Personnel' Model. Purpose of this study was to test the efficiency and effectiveness of the training model and find the determinant factors of teachers' development of critical thinking. This training model was developed through three stages. The training was attended 37 elementary teachers, 17 of them are alumni of SWCU Blended Learning Program. Based on the preliminary study found that primary school teachers perceived the training they have ever attended were not efficient and not effective, have not developed critical thinking skills; After the training model implemented is proven to be efficient and effective; There are 3 models of determinant 1) knowledge elaboration, 2) participation of teachers, and 3) best image result of the critical thinking skills of teachers of SWCU blended learning program.
\end{abstract}

Index Terms-'Training and Development Personnel', efficiency and effectiveness, critical thinking, participation of teachers, knowledge elaboration, good image result.

\section{INTRODUCTION}

Critical thinking skills are essential skills for life, work, and function effectively in all other aspects of life. The role of teachers is now more complex than ever before, for example, how teachers respond to the diverse needs of students are constantly changing as a result of such rapid technological developments and the demands of the community to achieve excellence, as well as changes in the social construction of society and globalization [1]. The quality of the students in the future is determined by the role of teachers in today's schools. Until now the school is a social institution that is organized to develop the students prepare for the future generations of this nation. Therefore schools and teachers are expected to develop and renew ourselves continuously to be able to keep pace with the changes in the needs of students and society.

A teacher is an agent of change. Teachers are expected to play a role to bring positive changes for the students and

Manuscript received July 23, 2013; revised November 8, 2013.

Slameto is with Primary School Teacher Education, Faculty of Teacher Training and Education, Satya Wacana Christian University Salatiga, Indonesia (e-mail: slameto_uksw@yahoo.com). school. In addition to the role played in the context of the curriculum, learning and evaluation, a teacher is also exemplified by the students in terms of personal habits that make [2]. The results World Bank research stated that the Indonesian teachers are the lowest in Asia in its role as an agent of change [3], productivity is very low [4] many factors that influence it.

Associated with the development of critical thinking, the practice of teaching and learning by teachers in primary schools, encouraging the achievement of the necessary critical thinking skills. According to Anderson, there are 2 factors cause not develop critical thinking in education during curriculum is generally designed with a target of extensive material so that teachers are more focused on the completion of the materials and teachers' lack of understanding about the teaching methods that can improve critical thinking skills [5].

By becoming a critical and inspiring teacher expected a figure that is able to motivate and to inspire the students, so that students are able to optimize the potential of their critical thinking that is useful for the future. Critical and inspiring teacher who is driving change; however what about the condition of our teachers were described by the World Bank study and the second factor as revealed by Anderson? Therefore need to empower teachers. If so, which model of teacher training? One model of teacher empowerment training is ' Training and Development Personnel' model of Otto and Glaser [6], which is considered quite effective. Further problems what are the factors that influence and how to model the relationship between factors in order to improve critical thinking skills of teachers, especially teachers graduate from SWCU blended learning program (Distance Education)?

The problem in this research is how the development of teacher 'Training and Development Personnel' model to improve critical thinking skills of teachers? What factors determine/determinant, as well as how the model and the contribution to the improvement of critical thinking skills teacher trainees? The purpose of this study was to test the efficiency and effectiveness of the 'Training and Development Personnel' model and find the determinant factors determining a teacher of critical thinking skills.

\section{THEORY}

Critical thinking is a cognitive activity related to the use of reason. Learn to think critically means using mental processes, such as attention, categorizing, selection, and assess/decide. Critical thinking skills give the right direction 
to think and work, and assist in determining the relationship with the other with something more accurate. Therefore, the critical thinking skills needed in solving the problem and management tasks [7]. Developing critical thinking skills is an integration of several development skills: observation, look at the information from various perspectives, analysis, reasoning, judgment, decision making, and persuasion. The better development of these abilities, the more we can address complex problems with satisfactory results.

Learning to develop critical thinking emphasizes the importance of focusing on learners attempt to actively analyze and solve a variety of problems that exist around including in their learning process; Kember [8] states that a lack of understanding about the teaching of critical thinking has a tendency to not teach or perform an assessment of students' thinking skills. Often the teaching of critical thinking as a means of problem solving, although the ability to solve problems is part of the critical thinking skills [5].

Factors that determine the success of the program is teaching thinking skills training for tutors. But keep in mind that training alone will not affect the increase thinking skills if the application does not conform to the desired expectations, not accompanied by adequate administrative support, and the program is not being run in accordance with the student population [9].

Training strategies that can improve critical thinking skills, namely: 1) learning through small group discussion group, 2) use relevant context such as the problem with the training materials that are understood by the participants to improve critical thinking skills, and 3) the method of evaluation that requires study deeper, encouraging participants to learn in a more meaningful not just memorize [10]. Group learning methods collectively and/or ability to work together is needed. In addition to learning to overcome personal weaknesses, which usually hit within the limitations of the self, working in a group is also a characteristic of modern developments lately. Effective collaboration is usually offset by the inquiry personal skills continuously. Collaboration space in the school seems to reveal itself in the willingness for example through cooperative learning.

Education and training as an integral system is a set of components or elements or sub-systems that interact to change the competence of teachers' work so that he/she could do better by learning in education and training activities [11]. Approach in education and training system consists of a series of components of the input, process, output, and outcome. The input is the education and training of participants and lecturers with its competence, budget, time, facilities and infrastructure. Process as a sub-system in education and training is a learning process, evaluation of pre and post education and training, structuring class infrastructure and so on. The output is the result of education and training after completion, among other papers/materials, mastery of specific capacity. Output is a graduate education and training that has competence in accordance with the expected, certificates, statements of work entered the world, MIS. Outcome among others is increased productivity of graduate or graduate contributions made to the organization.

Based on the analysis of the needs of education and training targets are set; Goals should be clear what is to be achieved according to the results of analysis needs. Application of the principle of good study needs to be applied to the learning process can be done quickly and precisely. Basically learning principles are worth considering to apply revolved around five things: participation, repetition, relevance, transfer and feedback. The appropriateness of the teaching technique used depends on a variety of considerations that you want highlighted, such as frugality in finance, program materials, the availability of certain amenities, preferences and abilities of participants, preferences and ability to coach and learning principles to be applied. Having implemented the education and training can be identified teacher benefits, such as increased knowledge and skills as well as skills. Implementation of an education and training program can be said to be successful if the participants transform themselves, with increased capability in performing the task and behavioral changes that reflected for example in attitude, discipline and work ethic.

One of the efforts to improve the competence of teachers is the organization of education and training competency effective [11]. The structure of education and training programs to meet the required competencies need to be designed in a comprehensive manner. Development structures a comprehensive education and training is expected to increase competence as an educator. Some things that should be developed in education and training, including: identification of information related to the competence of the ideal, real competencies owned by teachers in the field, especially the education and training of prospective participants. The map is the basis for the formulation of competency goals, education and training materials, the experience needs to be developed, learning resources, allocation of time for education and training.

The next thing is the use of strategies that are relevant to education and training participant characteristics; packaging education and training materials into forms that facilitate active learning, fun, experience-based, competency based development, designing effective training scenarios, controlled, and accountable. Relevance of education and training necessary for the implementation of obtaining a positive response from the participants. For these purposes should: planning education and training through an assessment process to the education and training needs.

The use of delivery strategies needs to pay attention to things like the following [12]. Andragogy approach based on the application development experience and performance; Experience participant education and training should be developed in the form of active learning, allowing participants to be the subject of education and training activities in the learning process. With the experience and engagement work activities during the implementation of education and training are expected to develop skills in education and training is more impressive and stronger internalized so embedded; Education and training carried out in an interesting, impressive, and fun, as well as carefully evaluated; involvement of participants in the activity implementation of education and training provides an atmosphere of mental, emotional, social, and physical activity can make a distraction training atmosphere is more "alive" and participants will be followed by lackluster; 
Reflection sustainable integrated, for example in the form of FGD, needs to involve various stakeholders. Reflection is needed to see the cracks weaknesses as feedback for further improvement.

Appropriate systems approach as described above, can be identified the factors that influence the success of a good education and training related to the input and the education and training process itself; mentioned factors such as: clear \& meaningful task, cooperative-anticipative activity, cooperative learning experience based methods, cooperative and correlative, participative, exhibition result, elaboration of knowledge, critical thinking, reflection and anticipative thinking, enthusiastic, good image result and positive habits.

\section{DEVELOPMENT MODEL}

There are many models of instructional systems design. Among them there are system-oriented models, such as the Dick \& Carey Model, ADDIE Model, and others. There is also a model of instructional design-oriented products, because learning to produce products, such as the model Hannaffin \& Peck or rapid prototype models. Also, there is a model-oriented teaching and learning activities in the classroom, such as ASSURE, ICARE models.

In general, training design steps starting from the stage of analysis, design, development, implementation and evaluation. Evaluation can be done for each step from analysis to evaluation. This training system allows participants to absorb information/ knowledge, perform skills, interact deepen knowledge and skills, and reflect on what has been learned. Fifth above it is a requirement of a successful training design

Otto and Glaser [5] proposed training strategy development model with the term 'Training and Development Personnel' Model. This model consists of five activities: 1) analyzes practice problems, 2) formulate and develop training objectives, 3) selecting training materials, learning media, methods and techniques of training, 4) develop curricula and units, exercises, and topics training, and 5) assess the results of the exercise. An effective training model is considered capable when based curricula, approaches and strategies that fit the needs of the target learners and learning problems that occur in the middle of it. For the special requirements needed to build a model of an effective and efficient training. These requirements include the need/problem trainees learning.

An analysis phase typically includes several steps, such as systems analysis, which generally depict clients are asked to be involved in designing training. Formulation of objectives and tasks participants attended the training set, typically followed by reflection. After the selection of materials and media, followed by the quality of the training methods under the inspiration of trainee teachers. Once the curriculum and units, exercises, and training topics are set and implemented further training, after that need to be evaluated. The evaluation was done to determine whether the training program objectives achieved or not, and to determine if the content and training administrative satisfactory or not, to determine the benefits and costs financial program and to compare the costs and benefits of various training programs in order to choose which program is best for sustainability in the future.

'Training and Development Personnel' Model which consists of five steps was developed through three stages: a preliminary study, the development model of teacher education and training, continued validation of the model by evaluating the efficiency and effectiveness of the model in the form of self-assessment training participants.

\section{MeAsurements And Results}

Context 'Training and Development Personnel' Model is, as mentioned above, which consists of five steps activities are grouped into three stages, namely:

1) Preliminary studies that include analyzing problems exercise

2) Planning and Development Model that includes step: formulating and developing training objectives, selecting training materials, learning media, methods and techniques and develop curricula and training units, exercises, and training topics, and implement

3) Validation of models including step further assess the results of the exercise are used as the basis to develop models and learning strategies.

Based on the preliminary study found that during this time many teachers have problems related to teacher professional development related to both low mastery of pedagogical competence first professional competence that leads to the implementation of the duties and functions of the lower quality teachers. Based on the preliminary study found that during this time many teachers have problems related to teacher professional development related to both low mastery of pedagogical competence first professional competence that leads to the implementation of the duties and functions of the lower quality teachers. Training for primary school teachers have not been efficient and effective and not yet developed the ability to think critically; Therefore agreed to design appropriate training model (Training and Development Personnel).

Implementation training for elementary school teachers was held in the studio of the Working Group on Teacher Wonosobo Regency on May 2 - 102013 by the faculty facilitator SWCU Salatiga. The training participants were 37 people and 17 of them are alumni of SWCU Blended Learning Program.

TABLE I: VARIABLE DESCRIPTION AND ResUlts TRAINING PROCESS
\begin{tabular}{|l|c|c|c|}
\hline Variables & Mean & Me & SD \\
\hline Efficiency & 3,33 & 3 & 0,63 \\
\hline Critical Thinking & 2,93 & 3 & 0,62 \\
\hline
\end{tabular}

After the first and second step is done, the model validation performed. Model validation step 'Training and Development Personnel' this is by measuring the process and outcomes of training primary school teachers, which includes measurements of the level of efficiency, and effectiveness/ success of the training include increased ability to think critically. This activity is performed by conducting a self-assessment by participants of the training process that they follow and the results of the training they get. 
Participants' self-assessment results as Table I below are evidence of the efficiency and effectiveness of training.

Given the magnitude of the mean over the median, it can be stated that 'Training and Development personnel' model efficiently supports data. Thus Model 'Training and Development Personnel' can develop critical thinking skills of primary school teachers, although the results are not as expected, given the magnitude of the mean slightly below the median. Further description of the 11 independent variables thought to be determinants that influence the critical thinking skills of primary school teachers in the development of this training model is as follows.

TABLE II: DESCRIPTION OF THE 12 INDEPENDENT VARIABLES

\begin{tabular}{|c|c|c|c|c|c|}
\hline Variables & Mean & Me & SD & Min & Max \\
\hline $\begin{array}{l}\text { 1. Clear \& meaningful task } \\
\text { 2. Co-operative-anticipative activity } \\
\text { 3. Cooperative learning experiences based methods } \\
\text { 4. Cooperative \& correlative } \\
\text { 5. Exibition result } \\
\text { 6. Elaboration knowledge } \\
\text { 7. Reflection \& anticipative thinking } \\
\text { 8. Participative } \\
\text { 9. Enthusiastic } \\
\text { 10. Good image result } \\
\text { 11. Positive habits }\end{array}$ & $\begin{array}{l}3,0714 \\
3,2143 \\
3,3571 \\
3,2857 \\
3,2143 \\
2,9286 \\
3,0714 \\
3,2143 \\
3,2143 \\
3,2857 \\
3,0000\end{array}$ & $\begin{array}{l}3 \\
3 \\
3 \\
3 \\
3 \\
3 \\
3 \\
3 \\
3 \\
3 \\
3\end{array}$ & $\begin{array}{l}0,61573 \\
0,42582 \\
0,63332 \\
0,72627 \\
0,42582 \\
0,73005 \\
0,47463 \\
0,57893 \\
0,57893 \\
0,61125 \\
0,55470\end{array}$ & $\begin{array}{l}2 \\
3 \\
2 \\
2 \\
3 \\
2 \\
2 \\
2 \\
2 \\
2\end{array}$ & $\begin{array}{l}4 \\
4 \\
4 \\
4 \\
4 \\
4 \\
4 \\
4 \\
4 \\
4 \\
4\end{array}$ \\
\hline
\end{tabular}

Based on the results of the analysis as presented in the Table II, it turns out of 11 independent variables examined, most, 10 variables, such as the significant increase: 1) Clear and meaningful task, 2) Cooperative-anticipative activity, 3) Cooperative learning experience based methods, 4) Cooperative and correlative, 5) Exhibition result, 6) Reflection \& anticipative thinking, 7) Participative, 8) Enthusiastic, and 9) Good image result. There are only 2 variables are less well developed through this training, namely: 1) Elaboration knowledge and 2) Positive habits. Furthermore, to find the determining factors / determinants of teachers' ability to do critical thinking test Step Wise Regression models whose results are presented in Table III as follows.

TABEL III: MODEL SUMMARY

\begin{tabular}{|c|c|c|c|c|}
\hline Model & R & R Square & $\begin{array}{c}\text { Adjusted R } \\
\text { Square }\end{array}$ & $\begin{array}{c}\text { Std. Error of } \\
\text { the Estimate }\end{array}$ \\
\hline 1 & $.672^{\mathrm{a}}$ & .452 & .406 & .47443 \\
2 & $.797^{\mathrm{b}}$ &. $\mathbf{6 3 5}$ & .569 & .40436 \\
3 & $.880^{\mathrm{c}}$ & .775 & .708 & .33288 \\
\hline
\end{tabular}

a. Predictors: (Constant), Elaboration knowledge

b. Predictors: (Constant), Elaboration knowledge, Participative

c. Predictors: (Constant), Elaboration knowledge, Participative, Good_image_result

Based on the results of the regression analysis as above, of the 11 independent variables, was obtained 3 influential models of its determinants of independent variables on critical thinking skills teacher standards error respectively. Elaborations of knowledge variables (model 1) influence the critical thinking skills of teachers was $40.60 \%$. Elaboration of knowledge level and participative (model 2) influences the critical thinking skills of teachers was $56.90 \%$. Elaboration knowledge, participative and best image result (model 3) influences the critical thinking skills of teachers was $70.80 \%$. In order to know how high the level of significance of each model it can be examined in Table IV below.

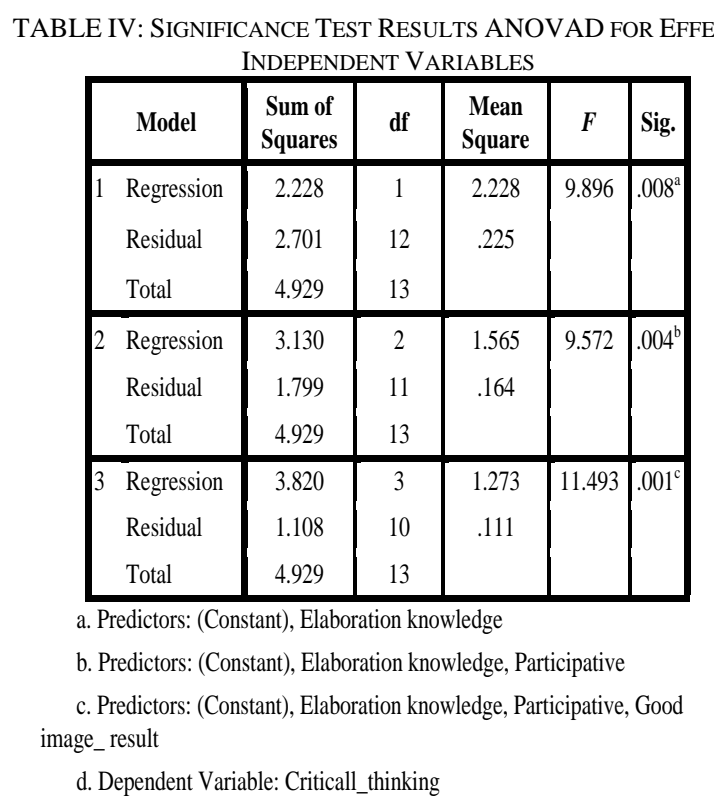

Based on the ANOVA results as presented in Table IV in the following, from the 11 independent variables, only 3 models obtained with only 3 variables into a variable determinant of the development of critical thinking skills of teachers, while the other 8 variables excluded from the model, because it is not significant. Model 1 is obtained $F=9.896$ with a significance level $=0.008$; This means that the variable elaboration knowledge be determinant developing critical thinking skills through training model of teachers 'Training and Development Personnel' by the influence of $40.60 \%$. Model 2 obtained at $F=9,572$ with a significance level $=0.004$; This means that the variable elaboration knowledge and participation of teachers be a significant determinant for the development of critical thinking skills through training model of teachers 'Training and 
Development Personnel' by the influence of $56.90 \%$. Model 3 obtained at $F=11,493$ with a significance level $=0.001$; This means that the variable knowledge elaboration, participation of teachers, and good image of the result being a significant determinant for the development of critical thinking skills through training model of teachers 'Training and Development Personnel' by the influence of $70.80 \%$.

\section{DISCUSSION}

Development 'Training and Development Personnel' model which was originally composed of 5 stages, modifications into three phases: 1) preliminary studies (analyzing training problems), 2) planning and development model (formulates and develops the training objectives, selecting training materials, learning media, methods and techniques and develop curricula and training units, exercises, and training topics, as well as execute), 3) model validation (assessing the results of the exercise). After the first and second step is done, by measuring the model validation process and results of primary teacher training, this includes measurements of the level of efficiency, and effectiveness/success of the training. It turns out that the model of training (Training and Development Personnel) supported the efficient and effective data.

A model of training is considered effective when able and based curricula, approaches and strategies that fit the needs of trainee teachers and the problems that occur in their midst. Three variables proved to be critical success training contributes $70.80 \%$ to the training priority in knowledge elaboration, and good participative image result. This means that the 'Training and Development Personnel' model will be successful if: 1) the curriculum or the quality of materials and method of training allows participants to build their own new and meaningful knowledge (elaboration), 2) applying cooperative learning which makes the teachers to actively participate in training, 3) the overall well-executed training stage and thus build a positive image of both the process and outcomes of training that they follow. These findings strengthen the theory of positive psychology and constructivism shown to be effective in training Model (Training and Development Personnel) for teachers, especially alumni of SWCU Blended Learning Program.

The training model consists of five steps which are then modified activities into 3 phases allows the teacher trainee cannot just absorb the knowledge, conduct/skilled, interact deepen their knowledge and skills, and reflect on what has been learned, but also to build new knowledge and meaningful to the lives of teachers; in other words it is a requirement 5 successful training design have been met. So it is feasible if the training is successfully developing critical thinking skills of teachers, supported by three significant independent variables, namely the knowledge elaboration, participation of teachers, and good and positive habits of result.

A teacher, alumni of SWCU Blended Learning Program with a strong personal vision always ask, and ask again, to clarify why the relevant intention to choose a profession as a teacher. A teacher will love the change so always update duties and functions as a professional teacher, so that's where training is undertaken, training relevant to the duties and functions along with the problem, done cooperatively with the support material are pushing to build new knowledge and meaning that will help develop a positive image about the process and the results of her training. It all will support the development of critical and creative thinking skills; When training tasks that followed the natural quality of training ultimately 'Training and Development Personnel' Model that they follow an effect on the ability of inspiring professionals as agents of change.

\section{CONCLUSION}

'Training and Development Personnel' model for primary teachers alumni of SWCU Blended Learning Program was efficient and effective; based on the results of the analysis, it turns out of 11 independent variables examined, most (9 variables), experienced significant improvement, namely: 1) clear and meaningful task, 2) cooperative-anticipative activity, 3) cooperative learning experience based methods, 4) cooperative and correlative, 5) exhibition result, 6) reflection \& anticipative thinking, 7) participation of teachers, 8) enthusiastic and 9) good image result. There are only 2 variables are less well developed through this training, namely: 1) knowledge elaboration, and 2) positive habits.

There are 3 models of the determinants influential independent variables on the critical thinking skills of teachers. The magnitude of knowledge elaboration variable (model 1) influences the critical thinking skills of teachers was $40.60 \%$. The magnitude of knowledge elaboration and participation of teacher's variables (model 2) influences the critical thinking skills of teachers was 56.90\%. The magnitude of knowledge elaboration, participation of teachers and good image result variables (model 3 ) influence the critical thinking skills of teachers was $70.80 \%$. Therefore, this model can be replicated in other groups of working teachers to improve the quality of teacher professionalism including improved critical thinking skills and ultimately improve the quality of teachers' duties and function is the advancement of education, especially for the improvement of elementary school.

\section{REFERENCES}

[1] Setyowati and M. Arifana, "Studi Keefektifan Pengembangan Pendidikan Masa Depan," Jurnal Pendidikan Dasar, vol. 5, no. 2, September 2004

[2] P. Sudira. (2012). Guru Sebagai Agen Modernisasi Pendidikan Dalam Dimensi Sosio-Kultural Untuk Peningkatan Kualitas Pendidikan. [Online]. Available: http://eprints.uny.ac.id/ id/eprint/656

[3] H. J. Giri. (2012). Pendidikan Usia Dini Masa Emas. [Online]. Available: www.hidayatjayagiri.net/

[4] World Bank. (2006). Mengefektifkan Pelayanan bagi Masyarakat Miskin di Indonesia: Titik Fokus untuk Mencapai Keberhasilan di Lapangan. [Online]. Available: http://ddp-ext.worldbank.org/ EdStats/IDNstu06a.pdf

[5] R. T. Pithers and R. Soden, "Critical Thinking in Education: A Review," Educational Research, vol. 42, no. 3, 1 October 2000, pp. 237-249.

[6] M. Kamil, Model-Model Pelatihan, Bandung: UPI, 2003.

[7] D. A. Prabowo. (2011). Berpikir Kritis. [Online]. Available: http://aldidoniprabowo. blogspot.com/

[8] D. Kember, "A reconceptualization of the research into university academics' conceptions of teaching," Learning and Instruction, vol. 7, pp. $255-275,1997$ 
[9] K. Cotton. (1991). Close-up \#11: Teaching thinking skills. Northwest Regional Educational Laboratory's School Improvement Research Series. [Online]. Available: http://www.nwrel.org/ scpd/sirs/6/cu11.html

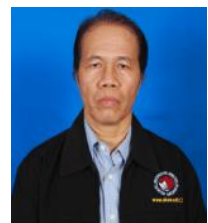

Slameto was born in the city of Salatiga on April 6,1953, who graduated in master on guidance and counseling and doctor on educational management from the State University of Semarang 2002.

He became a lecturer science 1982 and remains on course guidance and counseling and education of primary school teachers; He've written a book "Learning and the Factors That Influence It": Jakarta: Rineka Cipta, 2003. Prof Slameto is chairman of the Board of Education in Salatiga.

[12] M. S. Tutur, "Optimasi Diklat Kompetensi pendidik Sebagai Upaya Pengembangan Profesi Guru Berkelanjutan," Seminar Nasional Pengembangan Profesi Guru Berkelanjutan, Salatiga Tanggal, vol. 5 July 2011. 